\title{
PELATIHAN PENGEMBANGAN E-LEARNING UNTUK MENINGKATKAN INOVASI GURU DALAM PEMBELAJARAN DI SMK N 1 LINTONGNIHUTA
}

\author{
Edison Simamora \\ Sekolah Menengah Kejuruan Negeri 1 Lintongnihuta, Sumatera Utara, \\ edisonsimamora@gmail.com
}

\begin{abstract}
Abstrak: Tujuan penelitian tindakan sekolah ini adalah: (1) mengetahui penggunaan metode e-learning dapat meningkatkan proses pembelajaran guru mata pelajaran di SMK; (2) mengetahui bagaimanakah menerapkan pembelajaran metode e-learning untuk semua guru mata pelajaran di SMK; dan (3) mengetahui bagaimanakah peran dan kompetensi guru mata pelajaran SMK yang diperlukan dalam menerapkan pembelajaran dengan metode e-learning. Metode penelitian adalah penelitian tindakan sekolah, dengan subyek penelitian adalah SMK N 1 Lintongnihuta. Hasil penelitian ini menunjukkan bahwa: (1) menumbuhkan dan rangsangan bagi guru. Guru akan lebih bergairah belajar internet, email dan blogger karena mereka sadar dan menganggap itu suatu kebutuhan; (2) mampu memberdayakan sekaligus membuat guru aktif. dalam pembuatan setting internet, email dan blogger. Karena internet, email dan blogger; dan (3) guru akan terlatih melakukan praktik-praktik dan berinteraksi menggunakan e-learning bersama temantemannya tanpa mereka sadari sebelumnya dan juga dalam pengembangan pembelajaran inovatif dan kreatif untuk meningkatkan kompetensi guru.
\end{abstract}

Kata Kunci: inovasi guru, pembelajaran, pelatihan pengembangan e-learning

Abstract: The objectives of this school action research are: (1) knowing the use of e-learning method can improve the learning process of subject teachers in SMK; (2) knowing how to apply e-learning method for all subject teachers in Vocational High School; and (3) knowing the roles and competencies of vocational school teachers needed in implementing e-learning method. The research method is school action research, with the research subject is Vocational High School $N 1$ Lintongnihuta. The results of this study indicate that: (1) grow and stimulate teachers. Teachers will be more passionate about learning the internet, email and blogger because they are aware and consider it a necessity; (2) able to empower and make teachers active. in setting up internet, email and blogger. Because of the internet, email and blogger; and (3) teachers will be trained to do practices and interact using e-learning with their peers without them knowing it beforehand and also in developing innovative and creative learning to improve teacher competence.

Keywords: teacher innovation, learning, e-learning development training

\section{PENDAHULUAN}

Salah satu bidang yang mendapatkan dampak yang cukup berarti dengan perkembangan teknologi ini adalah bidang pendidikan, dimana pada dasarnya pendidikan merupakan suatu proses komunikasi dan informasi dari pendidik kepada peserta didik yang berisi informasi-informasi pendidikan, yang memiliki unsur-unsur pendidik sebagai sumber informasi, media sebagai sarana penyajian ide, gagasan dan materi pendidikan serta peserta didik itu sendiri (Oetomo dan Priyogutomo, 2004), beberapa bagian unsur ini mendapatkan sentuhan media teknologi informasi, sehingga mencetuskan lahirnya ide tentang e-learning (Utomo, 2001)

E-Learning berarti pembelajaran dengan menggunakan jasa bantuan perangkat elektronika, khususnya perangkat komputer (Soekartawi, 2003). Karena itu e-learning sering disebut juga dengan on-line course. Dalam berbagai literature $e$-learning tidak dapat dilepaskan dari jaringan Internet, karena media ini yang dijadikan sarana untuk penyajian ide dan gagasan pembelajaran. Namun dalam perkembangannya masih dijumpai kendala dan hambatan untuk mengaplikasikan sistem elearning ini, antara lain : (a) Masih kurangnya kemampuan menggunakan Internet sebagai sumber pembelajaran; (b) Biaya yang diperlukan masih relatif mahal untuk tahaptahap awal; (c) Belum memadainya perhatian dari berbagai pihak terhadap pembelajaran melalui Internet dan (d) Belum memadainya infrastruktur pendukung untuk daerah-daerah tertentu (Soekartawi, 2003). Selain kendala dan hambatan tersebut di atas, kelemahan lain yang dimiliki oleh sistem e-learning ini yaitu hilangnya nuansa pendidikan yang terjadi antara pendidik dengan peserta didik, karena 
yang menjadi unsur utama dalam e-learning adalah pembelajaran.

Pendidikan standar internasional dengan jejaring dunia maya (Cyber World) merupakan tantangan bagi perkembangan pendidikan di Indonesia, terutama daerah yang akses internet-nya masih sangat terbatas. Inilah tantangan yang akan merubah sistem pendidikan yang selama ini terpusat ke Pulau Jawa, Cyber World diterapkan dalam electronic learning yang biasa disebut dengan e-learning. Koran (2002), mendefinisikan e-learning sebagai sembarang pengajaran dan pembelajaran yang menggunakan rangkaian elektronik (LAN, WAN, atau internet) untuk menyampaikan isi pembelajaran, interaksi, atau bimbingan.

Maka dengan melihat kelemahan dan kekurangan tersebut, para ahli berusaha menjawab fenomena ini dengan mengembangkan sistem e-education. Sistem ini telah didiskusikan secara aktif pada beberapa dekade terakhir ini. Pengembangan sistem $e$ education ini telah memberi inspirasi untuk mengembangkan e-media secara optimal guna percepatan pemerataan layanan pendidikan kepada masyarakat (Oetomo dan Priyogutomo, 2004). Dimana selain masyarakat memperoleh pendidikan melalui pendidikan formal, juga didukung oleh pendidikan melalui emedia, sebagai wujud dari pendidikan yang mandiri.

Pengembangan keprofesionalan guru sangat terkait dengan kegiatan penelitian, khususnya Penelitian Tindakan Kelas (PTK) dan pengembangan pembelajaran dikelas dengan memanfatkan teknologi informasi (TI) yang sedang berkembang. Berdasarkan pada hal tersebut maka dengan kompetensi kepala sekolah/pengawas melalukan penelitian tindakan terhadap para guru-guru dalam pelatihan tentang "upaya peningkatan inovasi guru dalam pembelajaran melalui pengembangan metode e-learning" untuk meningkatkan profesonalisme pendidik melalui Penguatan Penelitian Tindakan Kelas (PTK ) dan Teknologi Informasi (TI)".

Sehubungan dengan fungsi tujuan yang sangat penting itu, maka suatu keharusan bagi guru untuk memahaminya. Kekurangpahaman guru terhadap tujuan pendidikan dapat mengakibatkan kesalahpahaman di dalam melaksanakan pendidikan. Gejala demikian oleh Langeveld disebut salah teoritis (Umar Tirtarahardja dan La Sula, 37 : 2000).
Proses belajar/mengajar adalah fenomena yang kompleks. Segala sesuatunya berarti, setiap kata, pikiran, tindakan, dan asosiasi dan sampai sejauh mana kita mengubah lingkungan, presentasi dan rancangan pembelajaran, sejauh itu pula proses belajar berlangsung (Lozanov, 1978). Dalam hal ini pengaruh dari peran seorang guru sangat besar sekali. Di mana keyakinan seorang guru atau pengajar akan potensi manusia dan kemampuan semua peserta didik untuk belajar dan berprestasi merupakan suatu hal yang penting diperhatikan. Aspek-aspek teladan mental guru atau pengajar berdampak besar terhadap iklim belajar dan pemikiran peserta didik yang diciptakan pengajar. Pengajar harus mampu memahami bahwa perasaan dan sikap peserta didik akan terlihat dan berpengaruh kuat pada proses belajarnya. (Bobbi DePorter : 2001)

E-learning (electronic learning) adalah pembelajaran baik secara formal maupun informal yang dilakukan melalui media elektronik, seperti internet, intranet, CD-ROM, video tape, DVD, TV, handphone, PDA, dan lain-lain (Lende, 2004). Akan tetapi, e-learning pembelajaran yang lebih dominan menggunakan internet (berbasis web). Keberhasilan pemanfaatan E-Learning environment yang terintegrasi tidak lepas dari berbagai aspek seperti tools teknologi informasi yang digunakan, desain content, metode serta perilaku belajar-mengajar siswa maupun guru dan lain-lain.

Dalam penerapan e-learning ada beberapa objek yang harus kita perhatikan agar proses belajar mengajar lebih interaktif antara pelaku pendidikan dan berkesinambungan. Dengan memanfaatkan website sebagai media yang dapat diakses kapan saja dan dimana saja dengan menggunakan komputer atau handphone sebagai interface pengguna dengan bahan adalah pendekatan interactive $e$-learning. Tapi ada makna yang bisa lebih mendekati ke pemahaman yang lebih tepat terhadap elearning ini, yaitu sistem pembelajaran yang tidak dibatasi ruang dan waktu, bisa dilakukan kapan saja dimana saja sesuka kita yang jelas pasti difasilitasi oleh alat elektronik baik itu handphone, laptop/netbook, personal computer yang terhubung jaringan ataupun stand alone dengan media bisa internet (online) dengan website, atau offline dengan menggunakan CD/DVD (Suyanto, 2005).

Menurut A. W. Bates (Bates, 1995) dan K. Wulf (Wulf, 1996) manfaat Pembelajaran 
elektronik Learning (e-Learning) itu terdiri atas 4 hal, yaitu:

1) Meningkatkan kadar interaksi pembelajaran antara peserta didik dengan guru atau instruktur (enhance interactivity). Apabila dirancang secara cermat, pembelajaran elektronik dapat meningkatkan kadar interaksi pembelajaran, baik antara peserta didik dengan guru/instruktur, antara sesama peserta didik, maupun antara peserta didik dengan bahan belajar (enhance interactivity). Berbeda halnya dengan pembelajaran yang bersifat konvensional. Tidak semua peserta didik dalam kegiatan pembelajaran konvensional dapat, berani atau mempunyai kesempatan untuk mengajukan pertanyaan ataupun menyampaikan pendapatnya di dalam diskusi. Hal ini disebabkan karena pada pembelajaran yang bersifat konvensional, kesempatan yang ada atau yang disediakan dosen/guru/instruktur untuk berdiskusi atau bertanya jawab sangat terbatas. Biasanya kesempatan yang terbatas ini juga cenderung didominasi oleh beberapa peserta didik yang cepat tanggap dan berani. Keadaan yang demikian ini tidak akan terjadi pada pembelajaran elektronik. Peserta didik yang malu maupun yang ragu-ragu atau kurang berani mempunyai peluang yang luas untuk mengajukan pertanyaan maupun menyampaikan pernyataan/pendapat tanpa merasa diawasi atau mendapat tekanan dari teman sekelas (Loftus, 2001).

2) Memungkinkan terjadinya interaksi pembelajaran dari mana dan kapan saja (time and place flexibility). Mengingat sumber belajar yang sudah dikemas secara elektronik dan tersedia untuk diakses oleh peserta didik melalui internet, maka peserta didik dapat melakukan interaksi dengan sumber belajar ini kapan saja dan dari mana saja (Dowling, 2002). Demikian juga dengan tugas-tugas kegiatan pembelajaran, dapat diserahkan kepada guru begitu selesai dikerjakan. Tidak perlu menunggu sampai ada janji untuk bertemu dengan guru/instruktur.

3) Menjangkau peserta didik dalam cakupan yang luas (potential to reach a global audience). Dengan fleksibilitas waktu dan tempat, maka jumlah peserta didik yang dapat dijangkau melalui kegiatan pembelajaran elektronik semakin lebih banyak atau meluas. Ruang dan tempat serta waktu tidak lagi menjadi hambatan. Siapa saja, di mana saja, dan kapan saja, seseorang dapat belajar. Interaksi dengan sumber belajar dilakukan melalui internet. Kesempatan belajar benar-benar terbuka lebar bagi siapa saja yang membutuhkan.

4) Mempermudah penyempurnaan dan penyimpanan materi pembelajaran (easy updating of content as well as archivable capabilities). Fasilitas yang tersedia dalam teknologi internet dan berbagai perangkat lunak yang terus berkembang turut membantu mempermudah pengembangan bahan belajar elektronik. Demikian juga dengan penyempurnaan atau pemutakhiran bahan belajar sesuai dengan tuntutan perkembangan materi keilmuannya dapat dilakukan secara periodik dan mudah. Di samping itu, penyempurnaan metode penyajian materi pembelajaran dapat pula dilakukan, baik yang didasarkan atas umpan balik dari peserta didik maupun atas hasil penilaian guru selaku penanggung-jawab atau pembina materi pembelajaran itu sendi

Menurut Bachtiar, dkk (2007) manfaat dari $e$ learning adalah :

1) Fleksibel. Memberikan fleksibelitas dalam memilih waktu dan tempat, kapan dan dimana saja, memiliki akses internet atau tidak. Banyak fasilitas yang sudah kita pakai saat ini untuk mengimplementasikannya seperti akses internet sudah bisa dimana-mana tidak harus ke warnet atau di sekolah/kampus bersangkutan, sudah banyaknya tersedia hotspot, Wi-Fi, WiMAX atau dengan memanfaatkan mobile technology, seperti : handphone, PDA, laptop/notebook. Atau bagi yang tidak memiliki koneksi internet, elearning dapat didistribusikan melalui movable media seperti : $C D / D V D$.

2) Efesien. Dengan e-learning kita bisa menghemat waktu dan biaya. Biaya pengelola dari administrasi dan sarana prasarana pembelajaran, biaya transportasi, akomodasi dan lain sebagainya. Sehingga biasanya waktu dan biaya yang selama ini kita boroskan dapat dihemat untuk kegiatan lain yang menunggu untuk dilakukan. Inilah yang membuat efektifitas kegiatan pembelajar semakin meningkat. 
3) Belajar Mandiri. Pernahkah kita melupakan untuk membuka e-mail, chating dalam seminggu? Bagaimana kita mengetahui informasi terbaru tanpa mengakses internet yang berubah setiap detiknya, bagaimana kita selalu termotifasi untuk mencari tahu lebih banyak membagi pengalaman dengan sesama dengan sukarela. Inilah yang melatih kemandirian pelajar diluar negeri sehingga kemampuannya dalam berfikir, mengolah materi dan menjabarkannya menjadi hal yang biasa. Bedakan dengan sistem pembelajaran yang kita terapkan selama ini yang hanya mengandalkan materi dari satu buku saja atau bahkan hanya mengandalkan informasi dari para pengajar saja.

Model pembelajaran berbasis TIK dengan menggunakan e-learning berakibat pada perubahan budaya belajar dalam kontek pembelajarannya. Menurut, Indrajit (2007), setidaknya ada empat komponen penting dalam membangun budaya belajar dengan menggunakan model e-learning. Pertama, siswa dituntut secara mandiri dalam belajar dengan berbagai pendekatan yang sesuai agar siswa mampu mengarahkan, memotivasi, mengatur dirinya sendiri dalam pembelajaran. Kedua, pengajar mampu mengembangkan pengetahuan dan ketrampilan, memfasilitasi dalam pembelajaran, memahami belajar dan hal-hal yang dibutuhkan dalam pembelajaran. Ketiga tersedianya infrastruktur yang memadai dan yang keempat administrator yang kreatif serta penyiapan infrastrukur dalam memfasilitasi pembelajaran.

E-learning merupakan alternatif pembelajaran modern yang dapat merubah paradigma pendidikan masa depan, dengan memadukan teknologi informasi sebagai gerbang pengetahuan dunia dengan kemandirian siswa-siswa serta pengajar lebih kreatif dalam menyediakan bahan ajar agar lebih menarik dan dapat diterima oleh siswa tanpa mengurangi daya serap mereka terhadap materi yang diberikan pada saat tatap muka dikelas.

Aplikasi web merupakan salah satu teknologi internet yang telah berkembang sejak lama dan yang paling umum dipakai dalam pelaksanaan pendidikan dan latihan jarak jauh (e-learning). Secara umum aplikasi di internet terbagi menjadi dua jenis, yaitu :
1) Synchronous System. Aplikasi yang berjalan secara waktu nyata dimana seluruh pemakai bisa berkomunikasi pada waktu yang sama. Contohnya : Chatting, Video Conference, dsb.

2) Asynchronous System. Aplikasi yang tidak bergantung pada waktu dimana seluruh pemakai bisa mengakses ke sistem dan melakukan komunikasi antar mereka disesuaikan dengan waktunya masingmasing. Contohnya : blog, e-mail, dll.

Dengan kondisi seperti ini tepat sekali e-learning diterapkan sebagai salah satu solusi terbaik dalam kesenjangan pendidikan selama ini. Untuk mendapatkan mutu pendidikan yang baik kita tidak perlu bersusah payah dan harus menyiapkan biaya yang sangat banyak demi mendidik siswa didik ke ibukota, yang kita butuhkan adalah dengan memanfaatkan elearning dengan cara efektif dan efesien "datanglah ke warnet terdekat". Dengan mengakses internet di warnet terdekat, peserta didik dapat mencari bahan ajar dari mana saja dan materi apa saja tanpa batas keilmuan, pengajar (guru) juga lebih aktif memodifikasi bahan ajar dengan yang lebih menarik dan bermutu bahkan bisa berinteraksi langsung dengan pelajar/pengajar diberbagai sekolah/kampus luar kota, pusat kota, propinsi dan ibu kota maupun yang ada diluar negeri. Proses belajar mengajar menjadi hal yang menyenangkan dan menarik dengan memanfaatkan teknologi terbaik saat ini.

Secara khusus permasalahan dalam penelitian ini dapat dijabarkan sebagai beikut: (1) Apakah penggunaan metode e-learning dapat meningkatkan proses pembelajaran guru mata pelajaran di SMK; (2) Bagaimanakah menerapkan pembelajaran metode e-learning untuk semua guru mata pelajaran di SMK; dan (3) Bagaimanakah peran dan kompetensi guru mata pelajaran SMK yang diperlukan dalam menerapkan pembelajaran dengan metode elearning

\section{METODE}

Penelitian dilakukan di SMK N 1 Lintongnihuta merupakan sekolah binaan pengawas. Sarana prasarana pengembangan manajemen pengelolaan program e-learning meliputi: (1) menentukan strategi yang jelas tentang target audience, pembelajarannya, lokasi audience, ketersediannya infrastruktur, budget dan pengembalian investasi yang tidak hanya berupa uang tunai. (2) menentukan 
peralatan misalnya hoste vs installed LMS dan Commercial or OS-LMS, (3) adanya hubungan dengan perusahan yang mengembangkan penelitian berkaitan dengan program e-learning yang dikembangkan di sekolah; (3) menyiapkan bahan-bahan yang akan dibutuhkan bersifat spesifik, usulan yang dapat diimplementasikan serta menyiapkan short response time.

Penelitian dilakukan selama program pelatihan berlangsung, yaitu empat kali pertemuan. Setiap pertemuan 4 (empat ) jam efektif. Pelatihan dilakukan di SMK N 1 Lintongnihuta yang sudah menggunakan $e$ learning dalam proses pembelajaran. Subyek penelitian adalah guru-guru SMK N 1 Lintongnihuta sebanyak 29 orang guru. Syarat kompetensi dasar yang harus dimiliki guru untuk menyelenggarakan model pembelajaran e-learning, adalah:

(1) Pertama kemampuan untuk membuat desain instruksional (instructional design) sesuai dengan kaedah-kaedah paedagogis yang dituangkan dalam rencanapembelelajaran.

(2) Penguasaan TIK dalam pembelajaran yakni pemanfaatan internet sebagai sumber pembelajaran dalam rangka mendapatkan materi ajar yang up to date dan berkualitas

(3) Penguasaan materi pembelajaran (subject metter) sesuai dengan bidang keahlian yang dimiliki.

Variabel harapan penelitian adalah: (1) proses pembelajaran melalui pengembangan $e$ Learning, dan (2) mengetahui upaya-upaya Upaya Membangun Budaya Belajar melalui Pengembangan model E-learning. Variabel tindakan penelitian adalah pembinaan guruguru SMK N 1 Lintongnihuta . Sumber data dalam penelitian ini berasal dari guru yang mengikuti program pelatihan pengembangan model pembelajaran e-learning. Pengawas dengan diperolehnya data selama proses pelatihan berlangsung sampai selesainya program kegiatan tersebut. Teknik pengumpulan data menggunakan: (1) wawancara, (2) observasi/ pengamatan, (3) angket/kuesioner, dan (4) dokumentasi

Penelitian tindakan yang dilaksanakan dalam dua siklus dianggap sudah berhasil apabila terjadi peningkatan dalam pelatihan pengembangan model pembelajaran e-learning guru mencapai $85 \%$ telah mencapai ketuntasan dengan nilai rata rata 75 . Jika peningkatan tersebut dapat dicapai pada tahap siklus 1 dan 2 , maka siklus selanjutnya tidak akan dilaksanakan karena tindakan kepengawasan yang dilakukan sudah dinilai efektif sesuai dengan harapan terhadap keberhasilan dalam menggunakan dan mengaplikasikan model pembelajaran e-learning dan dalam manajemen berbasis sekolah (MBS).

Guna meningkatkan kemampuan mengaplikasikan komputer dengan metode $e$ learning pada guru, peneliti menggunakan pelatihan dan pendampingan sebagai bentuk kegiatan pembelajaran e-learning di kelas. Pada setiap tatap muka selama 90 menit, guru-guru diminta secara aktif melakukan praktik mengoperasikan komputer dengan beberapa materi dalam pembelajaran e-learning, meliputi; (1) internet; pengertian dan sejarah internet, fasilitas-fasilitas internet, unsur-unsur website; (2) email; fasilitas google, membuat email, login dan mengirim email; (3) blogger; pengertian blogger, mendaftar dan member nama blog, pilih template dan posting data, dan upload gambar. Dengan perlakukan seperti ini, didapatkan asumsi bahwa kemampuan guruguru mata pelajaran di SMK N 1 Lintongnihuta akan meningkat. Adapun bagian detailnya akan didapatkan setelah penelitian ini dilakukan, dan itu akan disampaikan pada bagian kesimpulan.

Satu siklus meliputi empat langkah yaitu: perencanaan, pelaksanaan, pengamatan, dan refleksi.

\section{Siklus Penelitian}

Penelitian ini merupakan PTK yang menggunakan 3 siklus sedang dan dalam setiap siklus sedang terdiri atas 6 siklus kecil. Total jumlah siklus kecil dalam penelitian ini sebanyak 18 siklus kecil. Setiap siklus kecil berlangsung selama 90 menit. Pembagian siklus menjadi 3 siklus sedang dimaksudkan karena setiap siklus sedang memiliki karakter dan tujuan yang berbeda-beda.

Siklus sedang I memiliki karakter bahwa materi yang diberikan kepada guru; (1) internet; pengertian dan sejarah internet, fasilitas-fasilitas internet, unsur-unsur website; (2) email; fasilitas google, membuat email, login dan mengirim email; (3) blogger; pengertian blogger, mendaftar dan member nama blog, pilih template dan posting data, dan upload gambar. Tujuannya adalah untuk menumbuhkan sekaligus meningkatkan keberanian dan rasa percaya diri guru karena materi-materi tersebut pada dasarnya belum dikenal guru-guru,namun ada sebagian guru 
yang sudah mengenal materi tersebut. Siklus II, materinya dikembangkan satu tingkat gradenya di atas materi siklus 1 . Tujuan yang ingin dicapai adalah di samping untuk meningkatkan keberanian dan rasa percaya diri guru dalam pengembangan inovasi pembelajaran berbasis e-learning dan sekaligus untuk meningkatkan kompetensi guru dalam pembelajaran berbasis TIK . Sementara itu, siklus III, bobot materinya hampir sama dengan materi pada siklus II. Tujuan yang ingin dicapai adalah untuk meningkatkan rasa percaya diri guru, fluency, dan accuracy. Topik atau tema pada masingmasing siklus dapat dilihat pada bagian selanjutnya.

Sementara itu, yang dimaksud dengan siklus kecil adalah suatu kegiatan pembelajaran yang menyajikan satu anak tema atau topik tertentu dalam satu tatap muka selama 90 menit ( 2 x 45 menit). Setiap siklus kecil terdiri atas empat tahapan, yaitu planning, acting, observing, dan reflecting.

\section{Perencanaan}

Perencanaan adalah langkah awal yang dilakukan peneliti saat akan memulai tindakannya. Agar perencanaan mudah dipahami oleh objek yang melakukan tindakan, maka peneliti membuat panduan tindakan yang menggambarkan: (1) apa yang harus dilakukan objek, kapan dan berapa lama dilakukan; (2) di mana dilakukan; (3) fasilitas yang diperlukan; dan (4) jika tindakan sudah selesai, apa tindak lanjutnya.

\section{Pelaksanaan (Tindakan)}

Pelaksanaan adalah penerapan dari perencanaan. Hal-hal yang harus diperhatikan adalah: (1) apakah ada kesesuaian antara pelaksanaan dengan perencanaan?. (2) bagaimana kelancaran proses tindakan yang dilakukan objek yang melakukan tindakan?, (3) bagaimanakah situasi proses tindakan?, (4) apakah objek yang melakukan tindakan mampu melaksanakan tindakan dengan penuh semangat?, dan (5) bagaimanakah hasil keseluruhan dari tindakan itu?; (6) Kegiatan refleksi (perenungan, pemikiran dan evaluasi) dilakukan berdasarkan pertimbangan rasional (menggunakan konsep teori) yang mantap dan valid guna melakukan perbaikkan tindakan dalam upaya memecahkan masalah yang terjadi, dan (8) Tindakan perbaikan terhadap situasi dan kondisi pembelajaran dilakukan dengan segera dan dilakukan secara praktis (dapat dilakukan dalam praktik pembelajaran)

\section{Pengamatan}

Pengamatan dilakukan dalam pelaksanaan tindakan. Hal-hal yang diamati adalah unsur-unsur dari proses tindakan pada pelatihan pengembangan model e-learning. Pengamatan dilakukan dengan menggunakan format pengamatan. Pengamatan dilengkapi doku,mentasi atau untuk merekam peristiwa ketika guru sedang melakukan pelatihan $e$ learning, kemudian dibahas bersama ketika refleksi.

Tahapan pengamatan dan pencatatan semua aktivitas PTS dilakukan bersamaan dengan saat pelaksanaan. Pengamatan dilakukan pada waktu tindakan sedang berjalan, jadi keduanya berlangsung dalam waktu yang sama.

Data yang dikumpulkan dapat berupa data pengelolaan. Instrumen yang umum dipakai adalah lembar observasi, dan cacatan lapangan yang dpakai untuk memperoleh data secara objektif yang tidak dapat terekam melalui lembar observasi, misalnya aktivitas siswa selama pemberian tindakan berlangsung, reaksi mereka, atau pentunjuk-petunjuk lain yang dapat dipakai sebagai bahan dalam analisis dan untuk keperluan refleksi, meliputi : (1) data jumlah guru, (2) data kualifikasi guru, (3) data daftar hadir guru, data kinerja guru, sebagainya. Lembar observasi guna memperoleh data kedisipinan guru dan lapangan.

Data yang dikumpulkan dicek untuk mengetahui keabsahannya. Berbagai teknik dapat dilakukan untuk tujuan ini, seperti misalnya teknik triangulasi, membandingkan data yang diperoleh dengan data lain, atau kriteria tertentu yang telah baku, dan lain sebagainya. Data yang telah terkumpul memerlukan analisis untuk dapat mempermudah penggunaan maupun dalam penerikan kesimpulan. Untuk itu berbagai teknik analisis statitika dapat digunakan.

\section{Refleksi}

Refleksi dalam PTS mencakup analisis, sintesis, dan penilaian terhadap hasil pengamatan atas tindakan yang dilakukan. Jika terdapat masalah dari proses refleksi, maka dilakukan proses pengkajian ulang melalui siklus berikutnya yang meliputi kegiatan : perencanaan ulang, tindakan ulang, dan 
pengamatan ulang sehingga permasalahan dapat teratasi (Hopkins, 1993).

Tabel 1. Pokok-pokok Rencana Kegiatan

\begin{tabular}{|c|c|c|}
\hline \multirow[t]{4}{*}{ Siklus I } & $\begin{array}{l}\text { Perencanaan } \\
\text { Indentifikasi } \\
\text { masalah dan } \\
\text { penetapan } \\
\text { alternatif } \\
\text { pemecahan } \\
\text { masalah }\end{array}$ & $\begin{array}{l}\text { Masalah: Sebagian guru ( } 40 \%) \text { masih rendah inovasi dalam } \\
\text { mengaplikasikan pembelajaran dengan metode e-learning oleh guru. } \\
\text { Mengembangkan skenario peningkatan inovasi pembelajaran dengan } \\
\text { metode } e \text {-learning oleh guru. } \\
\text { Alternatif tindakan: } \\
\text { Menerapkan pemberian cara berinovasi dengan pelatihan metode } \\
\text { pembelajaran e-learning } \\
\text { Menerapkan pengakuaan/penghargaan. } \\
\text { Menerapkan sanksi. }\end{array}$ \\
\hline & Pelaksanaan & $\begin{array}{l}\text { Menerapkan tindakan mengacu pada skenario menginovasi } \\
\text { pembelajaran dengan metode } e \text {-learning oleh guru dalam mengajar. }\end{array}$ \\
\hline & Observasi & $\begin{array}{l}\text { - Melakukan observasi dengan memakai format observasi } \\
\text { - Menilai hasil tindakan dengan menggunakan format ciri-ciri } \\
\text { inovator. }\end{array}$ \\
\hline & Refleksi & $\begin{array}{l}\text { - Melakukan evaluasi tindakan yang telah dilakukan yang meliputi } \\
\text { evaluasi mutu, jumlah dan waktu dari setiap macam tindakan. } \\
\text { - Melakukan pertemuan untuk membahas hasil evaluasi tentang } \\
\text { skenario, dll. } \\
\text { - Memperbaiki pelaksanaan tindakan sesuai hasil evaluasi, untuk } \\
\text { digunakan pada siklus berikutnya } \\
\text { - Evaluasi tindakan I }\end{array}$ \\
\hline \multirow[t]{4}{*}{$\begin{array}{l}\text { Siklus } \\
\text { II }\end{array}$} & Perencanaan & $\begin{array}{l}\text { - Indentifikasi masalah dan penetapan alternatif pemecahan } \\
\text { masalah. } \\
\text { - Pengembangan program tindakan II }\end{array}$ \\
\hline & Pelaksanaan & - Pelaksanaan program tindakan II \\
\hline & Observasi & - Pengumpulan data tindakan II \\
\hline & Refleksi & - Evaluasi Tindakan II \\
\hline \multicolumn{3}{|c|}{ Siklus- siklus berikutn } \\
\hline
\end{tabular}

\section{HASIL DAN PEMBAHASAN Refleksi Awal}

Seperti yang telah peneliti uraikan pada awal bagian penelitian ini bahwa kemampuan guru dalam pembelajaran komputer berbasis $e$ learning amat rendah. Kondisi seperti ini sangat dipengaruhi oleh kebiasaan pembelajaran sebelumnya dan perkembangan penggunaan komputer sebagai media pembelajaran ke siswa yang belum dipersiapkan dengan bak dan matang kompetensinya. Ini terbukti dari hasil interviu yang dilakukan oleh peneliti didapatkan data bahwa kemampuan dalam menggunakan komputer, terutama dalam penerapan metode e-learning pada penggunaan internet, blog, google, dan upload, dan download guru-guru mata pelajaran si SMK rata-rata sangat rendah. Sebanyak $10 \%$ guru dapat menjawab pertanyaan yang diajukan dengan mendapatkan nilai kategori baik. Sebanyak 20\% guru mendapat nilai dengan kategori cukup. Sedangkan sisanya, sebanyak $70 \%$ guru mendapatkan nilai kategori jelek.

Di bawah ini daftar topik pertanyaan yang diinterviukan kepada guru, tentang: (1) internet; pengertian dan sejarah internet, fasilitas-fasilitas internet, unsur-unsur website; (2) email; fasilitas google, membuat email, login dan mengirim email; (3) blogger; pengertian blogger, mendaftar dan member nama blog, pilih template dan posting data, dan upload gambar.

\section{Siklus I \\ Perencanaan I}

Siklus I terdiri atas 6 siklus kecil, dan setiap siklus kecil berlangsung selama 90 menit. Materi yang diberikan antara lain: (1) internet; pengertian dan sejarah internet, fasilitasfasilitas internet, unsur-unsur website; (2) email; fasilitas google, membuat email, login dan mengirim email; (3) blogger; pengertian 
blogger, mendaftar dan member nama blog, pilih template dan posting data, dan upload gambar. lain:

Langkah-langkah yang ditempuh antara

1) Menjelaskan fungsi dan kegunaan internet sebagai media pembelajaran pada sumber belajar dalam upaya peningkatan guru pada pembelajaran e-learning.

2) Menjelaskan dan mempraktikkan jenis-jenis layanan internet, meliputi; Electronic Mail (E-mail), Email Adress, File Tranfer Protocol (FTP), Tele Networking (TelNet), E-Learning, User's Network (UseNet), World Wide Web (WWW), Internet Relay Chat (IRC), Internet Phone/Conference, WAIS Server, Gopher, Internet, Mailing List, dan Unsur-Unsur Web Site.

3) Menjelaskan dan mempraktikkan penggunaan e-mail, pada; (1) membuat email, meliputi alamatkan...http://mail.google.com, daftarkan diri, klik signup ke gmail, isi biodata diri, isi ferifikasi kata dan klik persetujuan, (2) login email, meliputi; isikan nama dan password, nama email anda akan tampil, (3) mengirim email klik tulis email, tulis email tujuan, pesan, dll, lebih dari 1 alamat, indikator email terkirim, (4) membika email, meliputi; klik surat masuk, klik arsip (email masuk) yang mau dibuka, membaca email masuk, (5) membalas email, meliputi; klik balas, ketik pesan, klik balas, indikator email terkirim, (6) menghapus daftar email, meliputi: klik kotak masuk, cek email yang akan dihapus, klik hapus, indikator daftar email telah terhapus, (7) mengirim email disertai file klik tulis email, email tujuan, klik lampirkan file lain, pilih dokumen, klik open, klik kirim, indikator email terkirim, klik kotak masuk, klik email yang akan dibuka, klik download semua lampiran, simpan file download, klik save, tempatkan file, indikator download.

4) Menjelaskan dan mempraktikkan penggunaan Blogger, pada; (1) login menggunakan account google, mendaftar, memberi nama blog, pilih template, blog telah di ciptakan, posting data, lihat blog kita, insert posting dengan gambar, upload gambar, indikator gambar telah di upload, menaruh gambar di bloger, tambahkan elemen halaman, memasukan elemen baru, tambahkan gambar, edit yang terposting, menghapus dan input gambar baru, dan mengganti warna.

5) Menyimpulkan internet sebagai media komunikasi dan informasi modern yang digunakan dalam proses pembelajaran oleh guru.

6) Menyimpulkan e-mail sebagai media komunikasi dan informasi modern yang digunakan dalam proses pembelajaran oleh guru.

7) Menyimpulkan blogger sebagai media komunikasi dan informasi modern yang digunakan dalam proses pembelajaran oleh guru.

8) Melaksanakan praktik dalam metode pelatihan penggunaan internet pada semua guru-guru dan dilakukan pembimbingan untuk mengoperasikan, membuka, dan mencari situssitus sebagai tugas untuk pengembangan materi pembelajaran berbasis e-learning

\section{Pelaksanaan I}

Peneliti diminta mempraktikkan secara langsung pada guru-guru dalam pembelajaran e-learning pada penggunaan internet, dan dipandu oleh instruktur untuk dapat mengaplikasikan langsung. Untuk satu komputer untuk satu guru, sehingga memudahkan guru melakukan pekerjaan yang berkaitan dengan e-learning.

Untuk topik-topik yang lebih rumit, kegiatan ini kadang-kadang membutuhkan lebih dari 15 menit. Selanjutnya setelah guru merasa jelas, peneliti meminta guru mempraktikkan cara mengakses situs internet selama kurang lebih 15 menit. Pada saat guru membuka internet, peneliti melakukan pemantauan dan memberikan balikan atau bimbingan. Karena untuk mengoperasikan internet untuk masingmasing guru bebeda-beda, artnya tidak semua guru mengetahui nternet secara jelas.

Peneliti selanjutnya memantau jalannya pelatihan sambil memberikan bantuan kepada guru. Untuk kesalahan-kesalahan yang bersifat umum, artinya dilakukan hampir seluruh guru, peneliti menjelaskan kembali secara klasikal. Sementara kesalahan yang dilakukan uru pada saat pelatihan berlangsung, peneliti langsung memberikan penjelasan pada guru untuk melakukan perbaikan dan pengembangan diri guru dalam pengembangan inovasi pembelajaran berbasis e-learning dan sekaligus untuk meningkatkan kompetensi guru dalam pembelajaran berbasis TIK .

\section{Pengamatan I}

Pada setiap akhir dua siklus kecil, Angket guru dibagikan. Ini dimaksudkan untuk mengetahui 
respons guru setelah mereka mempraktikkan pembelajaran e-learning pada penggunaan internet. Tabel berikut ini menunjukkan jumlah rata-rata respons guru, didapatkan data: (1) Guru merasa kesulitan membuka, mencari, situs-situs di intenet. Hal yang demikian mengakibatkan sebanyak $64 \%$ guru merasa kesulitan dalam menggunakan internet sebagai media pembelajaran berbasis web. (2) Peneliti sudah memberi contoh cara mendemostrasikan, saat membuka, mencati dan memilih situs-situs di internet dan secara langsung diberikan pada guru untuk sama-sama dipraktikkan, namun tidak banyak memberi penekanan sehingga mengakibatkan sebanyak $61 \%$ guru merasa kesulitan saat mempraktikkan.

\section{Refieksi I}

Sementara itu, hasil refleksi yang diperoleh di lapangan selama pelaksanaan siklus I sebagaimana di bawah ini. (1) Pada awal pelaksanaan siklus I tampaknya sebagian besar guru masih merasa canggung (tidak percaya diri) melakukan praktik mengoperasikan komputer dalam penggunaan internet berbasis web sebagai media pembelajaran yang digunakan oleh guru-guru. Sebagai gantinya, guru-guru dalam pelatihan ini banyak melakukannya dengan cara melihat pekerjaan teman-temannya yang mampu menggunakan internet dengan baik dan sering sekali menanyakan ketidak pahaman dalam mengoperasikan internet. Kondisi yang demikian terjadi karena guru belum terbiasa menggunakan internet. Kemungkinan lain, kurangnya penekanan pada penggunaan internet dan komputer secara keseluruhan. Masalah ini akan mendapat perhatian peneliti untuk pelaksanaan siklus sedang berikutnya; (2) Sebagian besar guru-guru merasa sulit beradaptasi dengan penggunaan komputer pada metode e-learning untuk meteri internet yang dipersiapkan sepenuhnya oleh peneliti. Keadaan ini akan mendapat perhatian peneliti pada pelaksanaan siklus sedang berikutnya. Misalnya, dengan memberitahukan terlebih dahulu tentang penggunaan internet untuk perternuan berikutnya, kemudian memberi penugasan kepada guruuntuk membuat persiapan-persiapan e-mail dan blogger sebagaimana yang dikehendaki.

\section{Siklus II}

\section{Perencanaan II}

Siklus sedang II terdiri atas 6 siklus kecil, dan setiap siklus kecil berlangsung selama 90 menit. Materi yang diberikan antara lain:

Langkah-langkah yang ditempuh pada perencanaan siklus sedang II antara lain:

1. Memberikan setting internet, email dan blogger terlebih dahulu untuk pertemuan berikutnya, dan memberikan penugasan kepada guru untuk mempersiapkan setting tersebut.

2. Menjelaskan dan menegaskan kembali kepada guru tujuan dan aturan penggunaan komputer guru dalam pengembangan inovasi pembelajaran berbasis e-learning dan sekaligus untuk meningkatkan kompetensi guru dalam pembelajaran berbasis TIK

3. Melatih guru dalam pemakaian internet, email dan blogger beberapa kali, sekaligus menjelaskan kegunaannya serta memberikan contoh agar mereka menjadi jelas di samping untuk meningkatkan guru dalam pengembangan inovasi pembelajaran berbasis e-learning dan sekaligus untuk meningkatkan kompetensi guru dalam pembelajaran berbasis TIK.

4. Memperpanjang waktu belajar internet, email dan blogger, semula 50 menit menjadi 60 menit.

5. Pengembangan inovasi pembelajaran berbasis e-learning dan sekaligus untuk meningkatkan kompetensi guru dalam pembelajaran berbasis TIK .

\section{Pelaksanaan II}

Guru diminta kembali mempraktikkan internet, email dan blogger sesuai dengan tujuan dan aturan permainan selama lebih kurang 60 menit. Untuk 5 menit pertama, guru membuat persiapan-persiapan sebagai setting internet, email dan blogger sebagaimana yang telah diberitahukan terlebih dahulu dan ditugaskan oleh peneliti. Guru tampaknya lebih mudah beradaptasi dengan setting yang telah mereka persiapkan sendiri. 5 menit berikutnya, peneliti menjelaskan tujuan dan aturan penggunaan internet, email maupun blogger. Pada bagian ini peneliti mengingatkan dan menekankan kepada guru untuk inovasi dan pengembangan pembelajaran dengan menggunakan internet, email dan blogger sebagaimana prosedurnya, dan bukan melihat pekerjaan temannya. Kemudian 15 menit selanjutnya melakukan pekerjaan dengan internet, email dan blogger sekaligus dijelaskan oleh peneliti fungsinya. Peneliti juga memberikan kesempatan kepada guru untuk menirukan cara memngoperasikan dan menggunakan perintah-perintah dalam 
pemngembangan inovasi pembelajaran berbasis web melalui guru dalam pengembangan inovasi pembelajaran berbasis e-learning dan sekaligus untuk meningkatkan kompetensi guru dalam pembelajaran berbasis TIK . Selanjutnya setelah guru merasa jelas, peneliti meminta guru mempraktikan internet, email dan blogger selama lebih kurang 35 menit dalam kelompok. Pada saat guru belajar internet, email dan blogger.

Peneliti selanjutnya memantau jalannya guru dalam mengoperasikan dan mengembangkan internet, email dan blogger, walaupun masih harus diberikan bantuan kepada guru. Untuk kesalahan-kesalahan yang bersifat umum, kesalahan itu dijelaskan kembali secara mendetail dan diberikan kemudahan dalam langkah demi langkah pengoperasian komputer untuk inovasi pembelajaran berbasis e-learning. Sementara kesalahan yang bersifat individu /guru atau kelompok, dijelaskan pada saat kesalahan itu terjadi. Namun demikian, koreksi yang diberikan tidak menjadikan guru down.

\section{Pengamatan II}

Pada setiap akhir dua siklus kecil, angket guru dibagikan. Ini dimaksudkan untuk mengetahui respons guru setelah mereka mempraktikkan internet, email dan blogger. Data yang diperoleh menunjukkan adanya penurunan dan peningkatan pada beberapa hal.

Dari semula 64\% guru yang menyatakan merasa kesulitan memahami internet, email dan blogger, kini turun menjadi $51 \%$. Ini dikarenakan peneliti tidak langsung mengartikan kata-kata itu, tetapi menggunakan gambar atau realia dan mungkin sangat diminati. Sehingga gambar itu dapat dijadikan guru sebagai alat cantolan untuk menambatkan kata-kata dalam benak mereka. Semula 58\% guru yang menyatakan mudah memahami internet, email dan blogger, kini meningkat menjadi $70 \%$. Ini disebabkan guru banyak berlatih. Di camping itu, guru juga sudah mulai terbiasa belajar internet, email dan blogger sehingga mereka juga terbiasa melakukan tanya dan jawab dalam e-learning. Demikian pula yang menyatakan sedang belajar internet, email dan blogger, semula dari $76 \%$ meningkat menjadi $82 \%$. Sementara itu, jumlah guru yang menyatakan sulit belajar internet, email dan blogger kini turun, semula 59\% menjadi $41 \%$. Ini tidak lain karena guru sudah terkondisi belajar internet, email dan blogger.

\section{Refleksi II}

Hasil refleksi yang diperoleh di lapangan selama pelaksanaan siklus II adalah sebagai berikut.

1. Rasa percaya diri guru selama pelaksanaan siklus sedang II tampak lebih baik dibandingkan pada siklus sebelumnya. Banyak guru yang tidak lagi melihat pekerjaan teman-temannya untuk mendapatkan dan memberi informasi. Melainkan mereka lakukan dengan bertanya dan menjawab dalam e-learning kendatipun cara menerapkannya masih belum terampil. Ini dikarenakan sikap peneliti yang sering membantu guru dalam e-learning pada siklus-siklus sebelumnya. Perpanjangan waktu untuk memperaktikkan e-learning tenyata dapat memengaruhi rasa percaya diri guru karena guru merasa lebih leluasa dan lebih lama melakukan praktik dengan metode e-learning ini.

2. Jumlah guru yang menggunakan pendekatan e-learning dalam mempraktikkan belajar internet, email dan blogger berkurang. Namun antusias guru dalam belajar internet, email dan blogger sangat tinggi. Karena waktu dan kesempatan yang perlu dibelajarkan kembali dapat mempermudah guru untuk dapat mempraktikan dalam pengembangan dan inovasi pembelajaran.

2. Belajar internet, email dan blogger dapat dilakukan oleh semua guru-guru pada saat pelatihan. suasananya tampak lebih meriah dan kondusif, hal ini mungkin disebabkan fitur-fitur serta kemudahan mengakses lewat komputer berbasis web sangat mudah dirasakan oleh guru. Faktor ini ternyata dapat memengaruhi keberanian dan rasa percaya diri guru sekaligus dapat mempertahankan guru untuk tetap melakukan praktik. Dalam kelompok belajar internet, email dan blogger guru melakukan hanya terbatas kepada pelatihan yang diberikan, namun sudah menunjukkan kemajuan yang berarti dan dapat terus ditingkatkan.

\section{Siklus III}

Siklus sedang III terdiri atas 6 siklus kecil, dan setiap siklus kecil berlangsung selama 90 menit. Materi yang akan diberikan belajar internet, email dan blogger dengan tingkatan yang lebih tinggi.

Langkah-langkah yang diberikan pada perencanaan siklus sedang III sebagai berikut.

1. Memilih materi-materi belajar internet, 
email dan blogger. Ini dimaksudkan agar rasa percaya diri dan fluency guru lebih meningkat. Dengan cara ini guru dapat berlatih serius, melatih rasa percaya diri mereka kepada teman-temannya yang sudah mampu melakukan e-learning dengan baik. Di samping itu, mereka juga dapat mengukur fluency mereka dibanding dengan teman-temannya.

2. Menambah waktu belajar internet, email dan blogger, semula 60 menit menjadi 75 menit. Ini dimaksudkan agar guru lebih lama melakukan praktik e-learning bersama teman-temannya.

\section{Pelaksanaan III}

Guru diminta kembali mempraktikkan belajar internet, email dan blogger sesuai dengan tujuan dan aturan permainan selama lebih kurang 75 menit. Untuk 5 menit pertama, guru membuat persiapan-persiapan sebagai setting belajar internet, email dan blogger sebagaimana yang telah dilakukan pada siklus sebelumnya. 5 menit berikutnya, peneliti menjelaskan tujuan dan aturan permainan. Pada bagian ini peneliti menekankan kembali kepada guru untuk melakukan belajar internet, email dan blogger sebagaimana prosedurnya, dan bukan melihat pekerjaan temannya. Kemudian 15 menit selanjutnya belajar internet, email dan blogger, sekaligus dijelaskan oleh peneliti fungsinya. Peneliti juga memberikan kesempatan kepada guru untuk menirukan cara mempraktikkan sampai beberapa kali hingga guru merasa jelas. Selanjutnya, peneliti meminta guru mempraktikkan belajar internet, email dan blogger selama lebih kurang 50 menit dalam kelompok besar. Pada saat guru belajar internet, email dan blogger, peneliti mencatat perkembangan dan kemungkinan apa yang harus dilakukan dan dikerjakan oleh guru-guru sesuai dengan bidang studi pada mata pelajaran masing-masing. Peneliti selanjutnya masih tetap memantau jalannya internet, email dan blogger sambil memberikan bantuan kepada guru.

\section{Pengamatan III}

Pada setiap akhir dua siklus kecil, Angket Guru dibagikan. Ini dimaksudkan untuk mengetahui respons guru setelah mereka mempraktikkan belajar internet, email dan blogger. Data yang diperoleh menunjukkan adanya penurunan dan peningkatan pads beberapa hal.

Dari semula $51 \%$ guru yang menyatakan merasa kesulitan belajar internet, email dan blogger, kini menjadi 31\%. Ini dikarenakan belajar internet, email dan blogger banyak yang dikenal oleh guru, ditambah lagi peneliti lebih banyak menggunakan gambar, realita dan mungkin gestur untuk membantu guru memahami artinya. Dari $70 \%$ guru pada siklus sebelumnya yang menyatakan mudah memahami e-learning yang dipakai dalam belajar internet, email dan blogger, kini meningkat menjadi $87 \%$. Kondisi yang demikian ini banyak dipengaruhi oleh latihan yang dilakukan terus-menerus oleh guru. Demikian pula yang menyatakan senang belajar internet, email dan blogger, semula dari $82 \%$ meningkat menjadi $91 \%$. Yang demikian ini karena belajar merupakan kegiatan yang disukai guru SMK. Jadi, wajar kenaikannya drastis. Sementara itu, jumlah guru yang menyatakan sulit belajar internet, email dan blogger kini turun, semula $41 \%$ menjadi $23 \%$. Ini tidak lain karena guru sudah terkondisi belajar internet, email dan blogger. Mereka sudah terbiasa dengan tujuan dan aturan-aturannya. Mereka juga tahu apa yang harus diperbuat dan harus mereka kerjakan selama belajar internet, email dan blogger.

\section{Refieksi III}

Hasil refleksi yang diperoleh di lapangan selama pelaksanaan siklus III adalah sebagai berikut.

1. Selama pelaksanaan siklus III, keberanian dan rasa percaya diri guru benar benar tampak. Sebagian besar guru, sekitar $90 \%$, tidak lagi melihat pekerjaan temantemannya untuk mendapatkan dan memberi informasi. Melainkan mereka lakukan dengan cara bertanya dan menjawab dalam $e$ learning. Fluency mereka juga tampak lebih baik dibandingkan siklus sebelumnya karena ungkapan-unkapan yang dipakai sudah banyak dikenal oleh guru. Demikian pula pada accuracy guru. Karena materi yang dipilih merupakan materi internet, email dan blogger yang dimainkan pada kelompok besar sehingga guru dapat melakukan dan menjawab melalui internet, email dan blogger.

2. Pada akhir pelaksanaan siklus III penggunaan guru dalam pengembangan inovasi pembelajaran berbasis e-learning dan sekaligus untuk meningkatkan kompetensi guru dalam pembelajaran berbasis TIK sudah tampak meningkat. Misalnya jika mereka. Guru begitu fasih menggunakan dan mempraktikan dalam pengembangan pembelajaran inovatif 
berbasis e-learning.

\section{PENUTUP}

Dalarn memberikan internet, email dan blogger sebagai kegiatan pembelajaran elearning, guru sebaiknya memerhatikan level guru, utamanya pada pemilihan materi. Internet, email dan blogger yang terlalu tinggi bagi guru dapat memengaruhi psikologi guru. Setting, tujuan, dan aturan permainan dalam internet, email dan blogger harus disampaikan agar dapat menumbuhkan rangsangan tersendiri bagi guru. Guru akan lebih bergairah belajar internet, email dan blogger karena mereka sadar dan menganggap itu suatu kebutuhan. Jika perlu guru juga dapat diberdayakan, misalnya dalam pembuatan setting internet, email dan blogger. Karena internet, email dan blogger yang balk adalah internet, email dan blogger yang mampu memberdayakan sekaligus membuat guru aktif. Dengan cara demikian guru akan terlatih melakukan praktikpraktik dan berinteraksi menggunakan $e$ learning bersama teman-temannya tanpa mereka sadari sebelumnya dan juga dalam pengembangan pembelajaran inovatif dan kreatif untuk meningkatkan kompetensi guru.

\section{DAFTAR PUSTAKA}

Anggoro, Mohammad Toha. (2001). "Tutorial Elektronik melalui Internet dan Fax Internet" dalam Jurnal Pendidikan Terbuka dan Jarak Jauh, Volume 2, No. 1, Maret 2001. Tangerang: Universitas Terbuka.

Departemen Pendidikan Nasional. (2002). Contextual Teaching And Learning. Jakarta: Direktorat Jenderal Pendidikan Dasar dan Menengah Direktorat Pendidikan Lanjutan Pertama.

Hidayat, Asep. "e-learning dan Kelas Jauh". Jurnal pendidikan dan Budaya. Diambil dari From http://educare.e-fkipunla.net. (01 September 2009)

Indrajit, Richardus Eko. (2007). e-learning dan penerapan TIK sebagai sarana penunjang Proses Belajar-mengajar. Makalah disampaikan pada Seminar Nasional Implementasi E-learning yang diselenggarakan oleh Universitas ATMA JAYA. Jakarta, 10 Desember 2008.

Kasali, Rhenald. (2008). New Way of Teaching : Menggunakan ICT Sebagai

Oetomo, B.S.D dan Priyogutomo, Jarot. (2004). Kajian Terhadap Model e-Media dalam Pembangunan Sistem e-Education, Makalah Seminar Nasional Informatika 2004 di Universitas Ahmad Dahlan Yogyakarta pada 21 Februari 2004.

Sidi, Djati Indra. (2003). Menuju Masyarakat Belajar. Jakarta : Paramadina pendukung Pendidikan. Indosat solution Day for Education. 18 November 2008

Suryabrata, Sumadi. (2004). Psikologi Pendidikan. Jakarta : Raja Grafindo Persada

Sutrisno. (2007). E-learning di Sekolah dan (sumber dari Internet: 17 Agustus 2007).

Suyanto, Asep Herman. (2005). Mengenal elearning.

Soekartawi, (2003), e-Learning di Indonesia dan Prospeknya di Masa Mendatang, Makalah Seminar Nasional 'e-Learning perlu e-Library' di Universitas Petra Surabaya pada 3 Februari 2003.

Sugiharto, Liliana. (2008). Lulusan bermutu dengan memanfaatkan e-learning. Seminar nasional yang diselengarakan oleh Universitas Atma Jaya. Jakarta.

Surjono, Herman Dwi. (2009). Pengantar elearning dan Penyiapan Materi Pembelajaran. Dimbil dari http://blog.uny.ac.id/hermansurjono/files/ 2009/02/pengantar-elearningdanpenyiapan- materi.pdf. (11 Oktober 2009)

Undang-Undang Republik Indonesia No. 20 Th. 2003 Tentang Sistem Pendidikan Nasional. Jakarta : Cemerlang

Utomo, Junaidi. (2001). Dampak Internet Terhadap Pendidikan : Transformasi atau Evolusi, Seminar Nasional Universitas Atma Jaya Yogyakarta, 7 April 2001. 